\title{
The Social Capital and the Development of Collaborative Networks in the Tourism Sector: a Case Study on The Grupo Gestor do Turismo Rural do Rio Grande do Sul (Rural Tourism Steering Group) - RS, Brazil
}

\author{
Capital Social e o Desenvolvimento de Redes Colaborativas: um Estudo \\ de Caso sobre o Grupo Gestor do Turismo Rural do Rio Grande do Sul - \\ RS, Brasil
}

\section{Capital Social y el Desarrollo de Redes Colaborativas: un estudio de caso sobre el Grupo Gestor do Turismo Rural do Rio Grande do Sul- RS, Brasil}

\author{
Isabel Angelica de Andrade Bock ${ }^{1}$ \\ Janaina Macke ${ }^{2}$
}

\begin{abstract}
This research aims to contribute to the inter-organizational network analysis perspective discussion, subsidized by the theories of collaborative networks and social capital. Elements based on social capital notions are recognized as greatly influencing collaboration and the actors' predisposition to collaborate. The qualitative method was adopted, using as techniques the documental research, the direct observation and interviews applied to the members of the Grupo Gestor do Turismo Rural do Rio Grande do Sul (the Rural Tourism Steering Group). The validity of these techniques application was considered to enrich the analysis and to better understand the relationship among the participant actors. Results show that in purposeful and operational terms the group can be characterized as a collaborative inter-organizational network, alternating moments of intense collaboration and independent work. Also relationships based on trust, norms of reciprocity, identification, elements related to social capital theory may be decisive for the group strengthening and continuity, as it is facing a period of transformation.
\end{abstract}

Keywords: Collaborative networks. Social capital. Brazilian rural tourism. Grupo Gestor do Turismo Rural do Rio Grande do Sul.

Resumo: Este estudo tem por objetivo contribuir para as discussões sobre análise de redes interorganizacionais, subsidiado pelas teorias de redes colaborativas e capital social. Elementos fundamentados nas noções de capital social são reconhecidos como grandes influenciadores da colaboração e da predisposição dos atores em colaborar. O método qualitativo foi adotado, utilizando as técnicas de pesquisa documental, observação direta e entrevistas aplicadas junto aos membros do Grupo

1 Universidade de Caxias do Sul (UCS). E-mail: isabel.angelica@terra.com.br

2 Universidade de Caxias do Sul (UCS). E-mail: jmacke@terra.com.br 
Gestor do Turismo Rural do Rio Grande do Sul. A validade da aplicação dessas técnicas foi considerada de forma a enriquecer a análise e melhor compreender a dinâmica de relacionamentos entre os participantes do grupo. Os resultados apontaram que, em termos propositivos e operacionais, o Grupo Gestor se caracteriza como uma rede colaborativa interorganizacional, alternando momentos de colaboração intensa e de trabalhos independentes. Também, que os relacionamentos pautados pela confiança, reciprocidade e identificação, elementos estes relacionados às teorias de capital social, podem ser determinantes para o fortalecimento e para a continuidade do grupo, que enfrenta um momento de transformação.

Palavras-chave: Redes colaborativas. Capital social. Turismo rural brasileiro. Grupo Gestor do Turismo Rural do Rio Grande do Sul.

Resumen: Este estudio tiene como objetivo contribuir a los debates sobre el análisis de redes interorganizacionales, apoyado por las teorías de redes de colaboración y capital social. Elementos basados en las teorías de capital social se reconocen como factores de gran influencia para la colaboración y la buena disposición de los agentes en cooperar. El método cualitativo fue adoptado, utilizando las técnicas de investigación documental, observación directa y entrevistas aplicadas a los miembros del Grupo Gestor do Turismo Rural do Rio Grande do Sul (Grupo de Gestión del Turismo Rural). La validez de la aplicación de estas técnicas fue considerada con el fin de enriquecer el análisis y mejor comprender la dinámica de las relaciones entre los miembros del grupo. Los resultados mostraron que, en términos proposicionales y operativos, el Grupo Gestor se caracteriza como una red de colaboración inter-organizacional, alternando momentos de intensa colaboración y el trabajo independiente. Además, las relaciones guiadas por elementos de confianza, reciprocidad e identificación, que se relacionan con las teorías del capital social, pueden ser cruciales para el fortalecimiento y la continuidad del grupo, que se encuentra en un momento de transformación.

Palabras-clave: Redes colaborativas. Capital social. Turismo rural brasileño. Grupo Gestor do Turismo Rural do Rio Grande do Sul.

\section{INTRODUCTION}

The regionalization and globalization issues have been widely discussed since the late twentieth century in different areas of knowledge. Both phenomena have generated discussions on the challenges, benefits and threats to sustainable development and the fierce competition between markets and tourism destinations with similar products. Processes ranging between homogenization and differentiation have been occurring all over the world. This reality has changed the way cities and even nations have structured touristic products and developed public policies.

The economic changes observed in recent decades altered the form of organization of many companies and also the organizational format of institutions. Public policies have called the participation of other actors than public ones to promote development in all levels of government. In this new socioeconomic scenario, networks began to take shape as a new organizational architecture, enabling the facilitation of information exchange and different types of knowledge, calling for the participation of the civil society on issues of mutual interest.

Following a global trend and what was pointed by the World Tourism Organization (WTO), Brazil gradually began to adopt a policy to decentralizing responsibility for developing and sustaining 
tourism. Different stakeholders were invited to participate, in order to implement actions that would provide conditions for an economically sustainable development, also a social and an environmental sustainability. Thus, since 2003, the Ministry of Tourism is requesting society's activities in different sectors (public, private and third sector) and levels (federal, state and municipal), motivating stakeholders to collaborate in planning, management and organizational activities, sometimes playing decision-making roles at local and regional levels (Brasil, 2006).

Some of the assumptions of the program of planning and management of regionalization (which are part of a macro program) include planning and consolidation of tourism segments by articulating and strengthening their representative bodies, also the intersectoral articulation and support of regional governance through networks. This program is being gradually implemented through management groups, advisory committees, deliberative councils, forums, among other modes of management. The program is also encouraging the local characteristics (identity) intensification as differentiation factors of tourism products. There are 11 segments that represent such features in 116 regions: Cultural Tourism, Rural Tourism, Ecotourism, Adventure Tourism, Sports Tourism, Nautical Tourism, Health Tourism, Fishing Tourism, Studies and Exchange Tourism, Business Tourism, and Sun and Beach Tourism (Brasil, 2006).

The tourism in rural areas, which has been increasing in Brazil considering a large number of properties listed in catalogs, websites and represented in events, such as the Salão Nacional do Turismo (national tourism trade show) e Feira Nacional de Turismo Rural (rural tourism national fair), has a strong appeal to rescue and to preserve the customs and enhance the live in the countryside, providing a richer supply of products and reaffirming the identity of the regions.

The tradition of Brazilian rural hospitality has its roots in colonization of the country, but as Beni (2006) has indicated, it is just from a few decades ago we can consider the visitation and tourists hosting on farms as an economic activity. Tourism in rural areas is considered a promising segment by both the public and private sectors, seeing as an alternative to destinations that are facing a saturation process, or for territories that are gradually losing their traditional productive function (Sharpley, 2002; Beni, 2006; Kastenholz \& Lima, 2013)

In the state of Rio Grande do Sul, the Secretaria de Estado do Turismo, Esporte e Lazer - SETUR (Secretary of State responsible for Tourism, Sport and Recreation) coordinates the "Rural Tourism Program" which aims to provide the optimization of structures, services and products offered and the promotion of new projects. Since 2007, actions are being handled by the Grupo Gestor do Turismo Rural (Rural Tourism Steering Group), which is composed by public and private institutions and by the third sector. The communication channel was improved among the rural entrepreneur sector reaching representativeness of all micro touristic regions of the state.

The research problem is concerned with the analysis of relations between representatives of government and private institutions and third sector organizations that constitute the Grupo Gestor do Turismo Rural do Rio Grande do Sul. The analysis is based on theories of collaborative networks (Camarinha-Matos \& Afsarmanesh, 2007; Rosas \& Camarinha-Matos, 2009) and social capital (Coleman, 1990; Putnam, 1995; Nahapiet \& Ghoshal, 1998; Macke et. al., 2012), and looks for evidences that may help to understand the group dynamics and the maturity level of interaction into it. These theories were chosen because they allow answering some key questions as: Can the Grupo Gestor do Turismo Rural be considered a collaborative network? If so, how is it working? Did the group reach the maturity level of interaction considered as collaborative? 
According to the social capital theory, it is likely that without the presence of a reasonable stock of social capital, the results achieved by the group could be insignificant and the creative collaboration process (predicted in the collaborative network theory) would not occur. In this context, social capital can be an important feature to the development of the rural tourism sector through elements like trust, cooperation, shared norms, reciprocity, commitment, among others, which are mentioned as major influencers for the support of collaborative networks.

Thus, in accordance with these theoretical sources, the following research question was formulated: How social capital and collaborative networks elements can be applied to understand the Grupo Gestor do Turismo Rural inter-relational dynamics?

\section{THEORETICAL BACKGROUND}

The collaborative networks, according to Camarinha-Matos \& Afsarmanesh (2007), are characterized by a group of entities (organizations and individuals) geographically distributed, who act mainly autonomously and heterogeneously (in terms of their operating environment, culture, social capital and goals), which decided to collaborate (usually through computer networks) to better achieve common or compatible goals.

The collaboration is a concept often confused with cooperation, but both have different values (Camarinha-Matos et al., 2009). Even though, the distinction between collaboration and cooperation are not clear, in a collaborative network, collaboration in its strict sense does not happen all the time alternating phases of intense collaboration and independent work. Physical or virtual interactions occur regularly to integrate practical results and to solve daily problems. During periods of collaboration, the members are more closely aligned in order to "work together", to achieve the desired result (figure 1 ).

Figure 1 - Interaction maturity levels

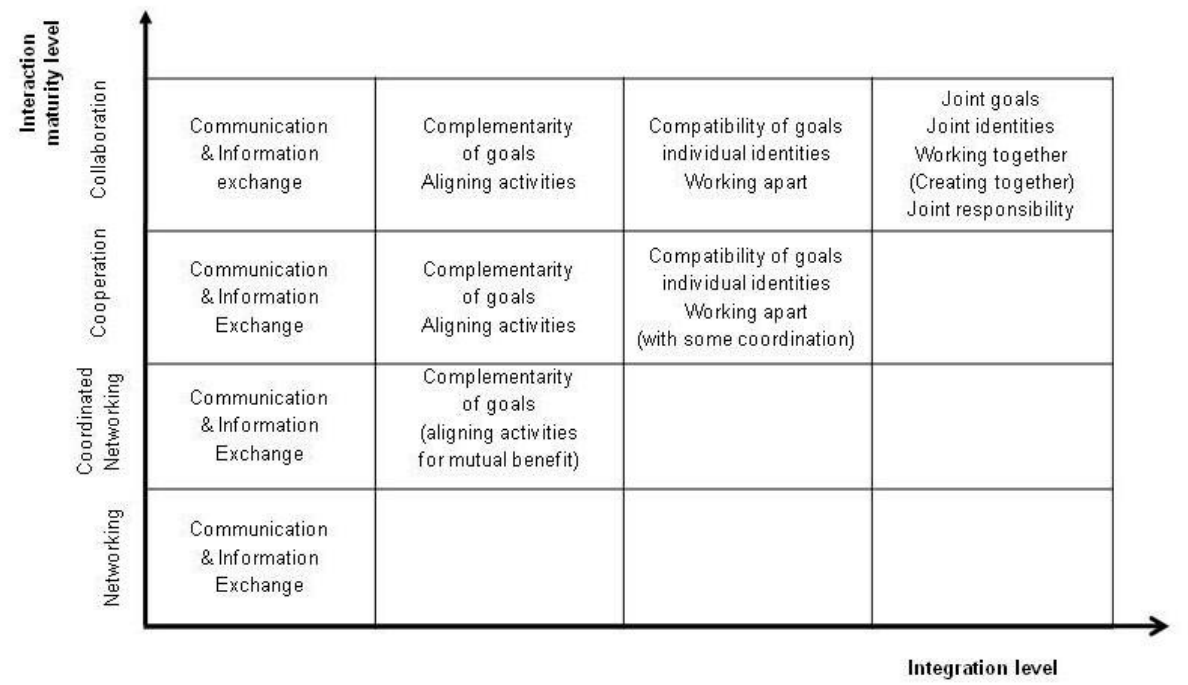

Source: Camarinha-Matos \& Afsarmanesh (2008, p.48).

In cases of long-term alliances, cooperation is a typical element (Camarinha-Matos \& Afsarmanesh, 2008).

The collaboration, a more mature level of all types of interactions, can be considered as a process of shared creation, i.e., a more demanding process, in which the entities go beyond the information and 
resources sharing, planning, implementing and evaluating a joint program. When involved in a collaborative network, organizations or individuals work together to achieve common (or similar) goals, in order to generate a universal value. In this sense the process improves the capacity of each member despite of involving risks, losses and rewards for everyone. According to the member's desire, the external network image can become a common identity through a unique and global feature rather than the individual one. However, working together can be challenging and risky. Often organizations can have a good performance when working alone and show poor performance when they work together. This means that before deciding to join a network, organizations must be prepared to collaborate in order to be ready to react quickly and take advantage of business opportunities (Camarinha-Matos et al., 2009; Rosas \& CamarinhaMatos, 2009).

A collaborative network demands that the potential partners be prepared to collaborate, including problems solving actions, operational standards compliance, establishment of cooperation forms, agreements acceptance and a trust basis among members. This collaboration process implies effort, time and dedication, as it is reasonable that some divergences occur. The creation of an incentive system that encourages proactive participation and recognition of individual contributions to the network is recommended, due to the fact that it creates transparent governance (Camarinha-Matos et al., 2009).

Recent researches show that some "soft" aspects like values, trust and norms are recognized as having a major influence in collaboration processes, affecting significantly partners behaviors, increasing the chances of success (or failure) of collaborative networks. On the other hand, "hard" factors, as competence or technological affinities, are seen as a preliminary phase to the formation of a network or partnership (Rosas \& Camarinha-Matos, 2009).

The search for ideal partners, the beginning of the collaboration process and the building of trust takes time, so members should be prepared to face some obstacles such as lack of information and infrastructure, and lack of promptness of organizations to work collaboratively. If the behavior patterns of individuals and organizations are seen as conducive to collaboration and are mostly positive, they are prepared to collaborate. In this sense, trust is an extremely important facilitator of collaboration (Camarinha-Matos \& Afsarmanesh, 2007; Rosas \& Camarinha-Matos, 2009).

It is common to face some difficulties in collaboration processes, in terms of resources, individual's contributions evaluation and the properties of intellectual creation. In this sense, it is necessary to set up, a common perception about the values exchanged by the members, from the beginning. Despite difficulties due to diverse values and beliefs, motivation to work is expected to occur, resulting from the basics of group cohesion, trust, and justice. Therefore, finding balance between collaboration and competition is a way of responding to external threats (and opportunities) to improve individual skills and generate innovations. These are the great challenges of a network: the definition of governance policies, the principles of working and sharing, and the tools to support infrastructure network (Camarinha-Matos \& Afsarmanesh, 2008).

The process of decision making in a collaborative network is influenced by both the system of common values, and the system of values adopted by its members (they may have different perceptions of results and different values, which can lead to non-collaborative behavior and interorganizational conflicts). Identify, characterize and define the value system of the network and its members is crucial when we try to improve the collaborative process. Consequently, a system of common values development is a significant element for the sustainability of collaboration, for it allows the key elements identification that create 
value in the network, avoiding misunderstandings and promoting the formalization of a shared understanding (Camarinha-Matos \& Macedo, 2010).

The lack of results objective measures of collaboration is a common obstacle in collaborative networks. The measurement of both individual and global benefits and performances can be presented as an important element for a wide acceptance of this organizational format (Camarinha-Matos et al., 2009).

One aspect to be considered in collaborative networks is that their actors' expectations are guided by the context and by the assessment of a recent situation that will happen in the future. Changes in the recent situation and the assessment of what will happen in the future may change expectations, which are subjective and depend, among other factors, on the personal interpretation of information and personal experiences in different scenarios. Meeting these expectations is a primary condition for trust development, because previous perception (positive or negative) affects its development. CamarinhaMatos and Afsarmanesh (2008) suggest that these expectations can be measured and used to predict and influence the success of a project (indicating the need to initiate a cyclical process of confidence building and fulfillment of expectations).

These authors point out that the success of a collaborative process depends on a number of requirements:

a) Must have a purpose (problem to be solved and goals to be achieved);

b) Members agreement (accepting experiences sharing) and the ability to know each other;

c) Goals sharing to keep the common view during the process (to achieve the universal goals);

d) Discussion on the progress of problems solutions;

e) Sharing what involves responsibility, participation in decision making, resources in terms of rewards, responsibilities and obligations, as well as, mutual trust (even though, partners may have different types of involvement, according to their roles).

Collaboration requires the determination of steps to be met: (a) identification of members and their meeting; (b) definition of the scope of the collaboration and desired outcomes; (c) definition of the structure in terms of leadership, roles, responsibilities, media, schedules, policies, evaluation mechanisms, among others; (d) identification of risks and contingency action plans; ( $f$ ) and the establishment of commitments among members (Camarinha-Matos \& Afsarmanesh, 2008).

Formulated in the early twentieth century, the concept of social capital is now widely applied in various areas of knowledge, mainly from the 90s. Because of this appropriation, it is still widely discussed and criticized for its flexibility and dynamics, seen as diffuse, broad, imprecise or ill-defined, while regarded as the "[...] missing link between the dependent and independent variables of economic growth models" (Muls, 2008, p.7). Although, it is seeing as an instrument of social analysis developed by individuals and even nations. It has several definitions and presents a diversity of approaches, according to the research field and the level of investigation required.

According to Portes (2000a), the first systematic contemporary analysis of social capital was produced by Pierre Bourdieu, in Europe. However, the propositions of James Coleman (1990), which combine approaches of sociology and economy, were particularly influential in the English-speaking countries, analyzing the social capital primarily as a way to better understand the relationship between education and social inequality (Albagli \& Maciel, 2003).

Both Bourdieu and Coleman emphasize the intangible nature of social capital, compared to other forms of capital, but Coleman believes that in order to possess social capital, an individual needs to relate to others, and these are - not himself or herself - the real source of social capital benefits (Portes, 2000b). 
What is observed is that, despite the diversity of defining and implementing the concept, it helps us to understand the mechanisms and extra-economic factors that contribute to the development, by accepting that "[...] there is something beyond the State and market as a coordination form of economic agents" (Muls, 2008, p.13).

Social capital is a broad concept that comprises networks and social norms that generate shared understandings, trust and reciprocity, which support cooperation and collective action for mutual benefit, and help to improve the efficiency of society (Dinda, 2008). Therefore, if well-defined, the concept can be a tool for consolidation of public policies, revitalizing civil society and democracy and contributing to sustainable development (by providing links among institutions and citizens for the common good). Its operationalization can also mean a "[...] valuable resource for implementing economic development policies and for evaluating the results of development projects" (D'Araújo, 2003, p. 8). The concept can be considered as the result of a consensus among economic and sociological theories (Muls, 2008).

The social virtues, including cooperative behavior and sense of duty towards others, are important to develop the individual virtues, and have received less attention in discussions of social capital (Fukuyama, 1996).

Social capital is defined by its function and is productive as much as other forms of capital. It is not an entity but a variety of them, with two elements in common: they all consist of some aspect of social structures and facilitate certain actions of actors - whether persons or corporations - within the structure. Social capital is the ability for people to act together towards common goals and specifies three ways: trust level; exchange information and ideas channels and norms and sanctions (Coleman, 2000).

Although the concept is used to investigate details of an organization, in order to understand the elements which are critical, it also allows to combine resources, to enhance performance, or in some cases, to achieve different results. According to Coleman (2000), the value of the social capital concept is in the identification of certain aspects of social structure, as resources for their functions (which can be used to achieve actors' interests). This concept is functional, multidimensional (micro, meso and macroeconomic) and manifold (civil, government, structural and cultural), and its interest lies in the fact that this feature enables the agent to engage in a social (collective) action (Muls, 2008).

If on one hand we believe that social capital can be stimulated through public policies by creating conditions more conducive to the development (participation in decision-making, voluntary and community activities), on the other, there is the argument that public policy intervention can represent exactly the reverse movement. If designed as a dynamic process of social relations, in which it builds tacit knowledge, social capital is closely linked to interactive learning and cooperation and the ability to have strategic community (Macke et. al., 2012). It can facilitate collective action, because of the dynamics (and density) of the interactions and changes and the learning process, which result from and is built by the social capital. In this sense, social capital is a determining factor for the ability to intervene and manage processes of change, allowing people to act not as passive recipients of outside interests (Barquero, 2002; Albagli \& Maciel, 2003).

Albagli and Maciel (2003) postulate that it is in the dynamics of the relationship between state and civil society that social capital is developed, indicating that this is the point where new challenges to public policies, and to the organization and social participation reside.

In this line, Nahapiet \& Ghoshal (1998) proposed a model that incorporates the arguments of several studies about social capital, which aimed to help identify important elements for intellectual capital creation. Their study was based on several authors concerned with the significance of relationships as 
resources for social action (Granovetter, 1985; 1992; Coleman, 1988; Burt, 1992; Putnam, 1993; 1995; Fukuyama, 1996; Mishira, 1996). The model proposed incorporated various aspects of social capital in different analytically and inter-relatable dimensions, describing how they facilitate the creation and the exchange of knowledge within organizations, and how these organizations may be able to develop high levels of social capital and consequently, intellectual capital. They considered social capital "as the sum of the actual and potential resources embedded within, available through and derived from the network of relationships possessed by an individual or social unit" (Nahapiet \& Goshal, 1998, p. 243).

This definition resulted in the setting of three dimensions: structural, relational and cognitive. In order to identify different aspects of social capital and to deepen its understanding, Nahapiet \& Ghoshal (1998) considered important to analyze these dimensions separately. Thereafter, these dimensions were used by other authors, like Lesser in 2000 and Inkpen \& Tsang in 2005, who believes that social relations involve three basic dimensions that influence the development of social capital: the structure of relationships, the interpersonal dynamics and the common context and language.

\section{THE GRUPO GESTOR DO TURISMO RURAL DO RIO GRANDE DO SUL (BRAZIL)}

This section covers the development of the tourism in rural areas in Brazil as a way to introduce the Grupo Gestor do Turismo Rural do Rio Grande do Sul (The Rural Tourism Steering Group). This study does not aim to discuss deeply the evolution of this tourism segment in Brazil. This subject can be easily found in the academic literature i.e. Graziano da Silva, Vilarinho \& Dale (2004), Tulik (2003), Portuguez (1999), Oliveira, Moura e Sgai (2001), Campanhola $(1999,2000)$ and Zimmermann (1996).

In order to explore the development of "rural tourism" in Brazil, it is relevant to consider two main aspects. The first is that, we chose to adopt the concept developed by the Ministry of Tourism, which considers "rural tourism" as a set of touristic activities developed in rural areas engaged in agricultural production, by adding value to products and services and by promoting the cultural and natural heritage of the community (Brasil, 2006). The second refers to economist José Eli da Veiga studies, that based rural on the parameters established by the Organisation de Coopération et de Développement Économiques (OECD), and alerts us to the fact that Brazil is predominantly rural (since most of half population lives in areas with a density below of 150 inhabitants per square kilometer). In fact, only 411 of the 5,507 Brazilian municipalities can be considered urban (Veiga, 2002). According to the author, due to the fact that the regions present rural and urban environment in different proportions, it is important to identify the most frequent types of development in each case (predominately rural, more or less rural and essentially urban). These areas may be dependent on local and regional markets, which it means that they do not rely just on visitors, but also on temporary residents (Veiga, 2002).

The Brazilian tradition of rural hospitality has its roots in the colonization history. However, was just a few decades ago that the reception and the accommodation of tourists in rural properties could be considered as an economic activity. Tourism in rural areas is considered a promising segment by both the public and private sectors, seeing as an alternative to destinations that are facing a saturation process, or for territories that are gradually losing their traditional productive function (Sharpley, 2002; Beni, 2006; Kastenholz \& Lima, 2013).

The literature indicates as a landmark for the rural tourism development, the emergence of the first rural tourist pole of the country, an initiative of the municipal government of Lages (state of Santa Catarina) and the local private sector, in the 1980s. This experience was an alternative use of the structure of beef 
and dairy farms (Silva, 2004). Tulik (2003) reveals that, for its pioneering, Lages is considered the National Capital of Rural Tourism and despite the development of other Brazilian regions, the most active nuclei are concentrated in the south and southeast of the country. Since 1983, the rural tourism has become an attraction in farm-inns of Lavras do Sul (RS), and has spread rapidly throughout Brazilian lands (Silva, 2004; Roque, 2001).

Twelve years later, the pioneering region already had more than a dozen properties involved with tourism, which brought its accreditation as a pilot project of rural tourism in the country, leading to EMBRATUR (the Brazilian Tourism Institute) to accept officially the segment in the National Municipalization Internalization and Tourism Program (Zimmermann, 1996). Carlos Solera, former president of the Brazilian Association of Rural Tourism (ABRATURR), notes that the official start of the activity took place in Lages with the opening of the first four farms to tourists. Proprieties have counted on the partnership with a Brazilian support service to micro and small enterprises, calls SEBRAE, which acted as a promoter of this new activity. In 1994, ABRATURR was formally created in the city of Lages (Rio Grande do Sul, 2010).

In response to a growing demand and the need of a set of rules aiming to the operationalization of the rural tourism activity, an operational manual was released by the Embratur in 1994 (Silva, 2004).

Tulik (2003) suggests that the rural tourism development in the country was so punctual and particular, with different characteristics and according to the interests of the more active landowners. This fact created the need for planning and the elaboration of national guidelines. Therefore, since 1998, planning workshops to support the segment nationwide began. Debates and seminars were promoted by EMBRATUR, in partnership with other institutions, such as the Ministry of Agriculture (Tulik, 2003; Silva, 2004)

In 2003, with the creation of the Ministry of Tourism and the new national policy adoption, the structuring program for tourism began to establish guidelines for the rural segment development. In 2007, the Grupo Gestor do Turismo Rural was established, as result of a collective discussion effort, determined to further strengthen the activity in Rio Grande do Sul state.

Currently, the number of enterprises involved in some way with the rural tourism has already reached around 15,000 farms and the segment is the fastest growing in the Brazilian tourism (SETUR, 2010). The growth of rural tourism is the result of, in one hand, the need that farmers have to diversify their source of income and add value to their products and, on the other, the desire of urban residents to rediscover their roots, to live with nature, with the lifestyles, traditions, and habits of people of the countryside (Brasil, 2004).

\section{RESEARCH METHOD}

The lack of previous studies regarding to the Grupo Gestor do Turismo Rural do Rio Grande do Sul and the desire to understand its dynamics as an interorganizational network (and intersectoral) were the triggering factors of this single case study, according to Yin (2005).

The case studies predominantly seek to understand the patterns that emerge from the data, rather than verify hypotheses, models or preconceived theories (Godoy, 2006). The research process started from the issues raised on the macro research project and from the search for recognized scientific work, since 
the study of similar phenomena could subsidize questioning, clarify doubts and contribute to the theoretical construction of the research (Hair Jr, 2005).

The literature research done resulted in a descriptive analysis of selected phenomena, based on organizational and social theories, and providing the establishment of relations between the networks, social capital and collaboration concepts.

According to the complexity of elements to be investigated and the nature of the problem and objectives to be achieved, we adopted the qualitative method, suitable for deepening the understanding of complex social phenomena and processes, as well as path dependence (Yin, 2005; Goldenberg, 1999). In this case, a holistic analysis is recommended to gather the most detailed information, to capture the totality of a situation and to describe the complexity of the case (Goldenberg, 1999).

An ethnographic approach was elected based on studies of Schwartzmann (1993) and Andion \& Servat (2006) on organizational networks. It was considered the following categories of events and routines analysis:

a) Participants - description of the members (speakers or broadcasters, listeners or recipients of messages) responsibilities and relationships;

b) Channels and codes - review of existing communication channels and their respective codes shared by the actors;

c) Space and time - observation of the length of time and the spatial arrangements where, formal and informal meetings take place;

d) Format - processes and events, including also the meanings attributed by the participants to such meetings;

e) Statements of the participants - expressions relating to topics of discussion and results, rules to talk and to interact, and oratorical styles, interest, participation and motivation of participants;

f) Rules of interpretation - examination of the processes that participants develop to interpret what happens in the meetings;

g) Objectives and results of formal meetings;

h) Cycles and patterns of meetings - relations between various types, in order to understand the role of meetings in the production and reproduction of social relations and cultural values and beliefs.

The observation during the group meetings of was an important instrument for data collection and also to perceive the relationships into the group. This technique, singular to the ethnographic method, enables the exposition of situations in a wider way. The fact is that an individual or group cannot sustain a compelled behavior over a long period of time while are being exposed to different situations (Goldenberg, 1999). In addition, we attended a regional conference held on September 2011, in the city of Caxias do Sul, located at Serra Gaúcha region - that has the largest number of rural tourism enterprises registered in the Rio Grande do Sul state.

On our first contact, documents were provided by the Tourism Secretary (SETUR-RS), to supplement information that was collected on its website.

The interviewing was another fundamental technique to explore the range of opinions, viewpoints and different representations. Considering the saturation point (Gaskell, 2003) we reached 14 respondents in total, including 11 coordinators and 1 former member of the group. 
For processing the collected information was adopted the content analysis, understood as a technique that analyses communications using a systematic and objective description of message content (Bardin, 2000). The categories were defined through the literature review, referring to the interaction maturity level; perceptions about threats to collaboration; and social capital elements. Based on that and the theoretical framework developed, the discussion of the results was performed.

\section{DISCUSSION}

The network approach allows the actors' perception identification regarding their interactions and their purposes, and therefore its dynamic procedure. The interaction between actors and organizations appears to broaden the range of options, in order to achieve common interests and projects, and to break through bureaucratic barriers. The idea is to preserve the heterogeneity in the group and seek flexibility, focusing on cooperate relations, but not eliminating the constructive conflict and competition (Loyola \& Moura, 1996).

[...] since we work with several different entities it is logical that there are different positions, because each one works in a segment. For example, SEBRAE works more on marketing and commercialization; SENAI works more on training programs and EMATER, on more specific technical rural issues. So what usually happens when there is a disagreement ... we try to deepen the issue to reach a consensus... and we normally reach this consensus... (Member 9).

According to Evans (1996), the existence of interlocutors belonging to the community may be an element to strengthen ties between government agencies and society. Therefore, the entrepreneurs participation into the group facilitates the communication. "We do direct contact, since we have been working for a long time and SETUR is a serious reference in this segment; we have contact with all projects". The Grupo Gestor has, as one of its premises, to stimulate the involvement of local communities. Some statements confirm community interest in the discussions: "when I say: tomorrow I will have the Group meeting, they get ready for it... When I return, I explain everything that was discussed. They are always eager to learn new things" (Member 1).

However, it was pointed out by some respondents who joined the group after the structure of the subgroups, the lack of incentives for collaboration: "[...] I arrived at a time when the Group had been articulated, the committees were already formed and I did not have room to insert myself, so I just followed" (Member 11).

\subsection{Interaction Maturity Level}

Camarinha-Matos and Afsarmanesh (2007) argue that potential partners should be prepared to collaborate. This construction takes time and requires: involvement in problem solving, compliance with operational standards, set up of cooperation formats, acceptance of agreements and a basis of trust among organizations. Among the members of the Group such construction took place gradually.

The meetings (physical or virtual) occur periodically in order to integrate results and encourage problem solving, including the formation of working groups with the aim of fulfilling a specific demand. "At the last meeting I participated, we saw the need to create a few more subgroups [....] I remember that, at this time, the Subgroup of Events and Fairs was created" (Member 3). Generally, the meetings followed a 
pattern: "[...] most of the meetings are informative; they are reports of participation in events and situations that have happened... few of them are performed for decision making" (Member 11).

The process of collaboration occurs when the members are more closely aligned in order to work together to achieve a desired result (Camarinha-Matos \& Afsarmanesh, 2008). At this stage or level of interaction, the shared creation and definition of shared resources and responsibilities for planning, implementation and evaluation of one program of activities takes place. This idea intended to make people work together to generate a universal value for the group.

One such moment occurred in the development of the rural tourism guide, as reported below:

a) "[...] it was developed, of course, by the whole Group, but headed by the Marketing subgroup" (Member 9);

b) "[...] this was a collaborative participation of all members. I think it's important to say that everyone contributed according to his/her conditions, one borrowed a car, another got an instructor ..."(Member 10);

c) "[...] my participation occurred in some areas that had not been served [...] my role was only as a partner to try to enable operational issues, such as transportation, for example ..." (Member 13).

Another situation, in which it is possible to observe more participation and interest, is when people have to deal with some change in legislation to solve the needs of rural entrepreneurs, in relation to tourism issues. The proposal of a bill that was processed at the Legislative Assembly, proposed by the Group is considered: "[...] a great evolution of the State Government, since it is one of a few Brazilian States that has this proposal for a law regulation of the tourism segment" (Member 5). Another respondent adds:

In fact, one of them was the mobilization issue for the sector organization, aiming to have a specific legislation, because it is difficult to delineate a strategic plan, to give a legal assurance, working on these issues, especially in business. [...] We gathered many times, pressuring political sectors [in the State Government], not only relating to technical issues, to create a draft law that was sent to the Assembly (Member 9).

The collaboration appears very clearly when the micro regions come together to participate in events that they consider important, as we can observe: "to participate in fairs under the flag of the Grupo Gestor do Turismo Rural is interesting, because it opens the possibility for the whole State to participate. It is a form of recognition for those who working in the sector" (Member 8).

The identification and the member's perception as a global unit can be perceived in the statements. The feeling of belonging can increase the interest in collective processes and in the group results, increasing cooperation:

[...] we have been evolving considerately in the State, being even a national model in the segment, because of the connection that exists between agencies and entities. Working with synergy, using the resources of each entity, increasing the results (Member 9).

[...] we know, we have achieved some goals ... I would like that other tourism sectors also had this same structure (Member 8 ). 
Evans (1996) points out that people who work in public agencies are often closely integrated into communities, creating social capital and overcoming public-private division. In this sense, some group members are frequently mentioned, showing the importance of key actors, especially SETUR.

One aspect to be considered in collaborative networks is the observation that the expectations of the actors are guided by the context. Changes in situations can change expectations, which are subjective and depend, among other factors, on the personal interpretation of information and his/her personal experiences. To reply to these expectations is the primary condition for the trust occurrence, as we can see in the statement: "The group has worked hard internally, and this has undermined some external actions. This is not just a problem of the group, this is a national problem of the tourism sector [...]" (Member 9).

\subsection{Perceptions about Threats to Collaboration}

Despite the positive view of subjects in respect to the collaborative process, some factors emerge from their statements (interviews, group meetings and regional conference). These can be viewed as harmful to collaboration. In the case of public agencies involved, synergy can go on, regardless of the incentives generated by political dispute. However, the positive possibilities that flow from competitive policies are likely to be extinguished, if public institutions are unable to provide what people need (Evans, 1996). Changes in public management have been generating frustration, changing people's behaviors and scenarios. Often, the feeling is that the situation has already been experienced and that the result is well known, so there is nothing to do besides what is requested: "[...] they just asked us, knowing that they could not accomplish what we have required. Then, we came to a point where we do not demand for more, because the minimum we needed, we did not receive. So, it was a non-sense, not to say other things [...], and I believe this reflect in the group actions" (Member 5 ).

As the references for the direction of the public agencies are political and may have representations from different parties, differences regarding to management can arise. These rivalries, different point of views and the ignorance of the activities complexity end up reflecting on another level in the chain, as the society (private sector, third sector and communities), bringing uncertainties. In this study, the expectation refers to the progress of activities and the continuity of the group.

The structuring process of the state policy of tourism, which began in 2011, brought the proposition of regional and state conferences. This has provoked different reactions to the group members. On one hand, this policy is supported, because it is expected that the construction of a public policy can remain without being affected by the trading influence of future governments: "[...] the project has to be an action plan of the State and not for just one government" (Member 7); "[...] what makes us happy... put us in the same level to discuss the new State policy, what did not happen before" (Member 5). On the other hand, there is some mistrust: "we will see if we can put it into effect. You know... sometimes things work well on paper and in practice don't" (Member 3).

Evans (1996) argues that in practice it is important to expand the existing social capital to create organizations that are broad enough. Thus, it is possible to effectively pursue development goals through the synergy, which is theoretically capable of capturing the complex interactions among social identities, norms and informal networks and formal organizational structures: "[...] the group is a space for this type of exchange, to look for alternatives and try to support the entrepreneurs and the rural sector as a whole" (Member 11). 


\subsection{Social Capital}

The relations analyzes are the aim of social capital theory. Concerning to the elements of the Nahapiet \& Goshal (1998) model, were highlighted those cited by Rosas \& Camarinha-Matos (2009). Aspects of structural, relational and cognitive dimensions foster elements perception such as cooperation, norms of reciprocity, commitment, which are identified as major influencers of collaborative networks support. It is possible to realize the importance of information exchanges, cooperation and commitment that the network provides:

[...] the group generates a huge learning experience, a much greater knowledge about what tourism really is. We want to do much more, because it is quite wide you can work a lot. Get in values and things like friendship, hospitality, respect and so forth (Member 1).

The collaborative process does not deter competition. However, referring to the relational aspect, the ideal is that cooperation replaces competition, and this has somehow been stimulated: "At the regional tourism fair, the presence of the group is always very important, because everyone is in the same boat. So, everyone is looking to help each other ... regardless of micro-region, we want to bring tourists to Rio Grande" (Member 2).

In the bylaws of the group, duties of members are explained. Information and materials are disclosed during the meetings in order to keep the group informed about demands of sub-regions, organizations and institutions. E-mails and other documents are sent at least twice a month. Also, locally, each member serve as interlocutor and information provider. This structural feature contributes to the access to information. Regarding the structural dimension, the network can be considered an appropriate organization, because its format and its procedures are reflected in the country: "[...] bringing the experience of how we did here, helping to build networks, giving a kick-off" (Member 14).

The respondents indicate that everyone is welcome to the group. This includes both new staff of public agencies, as representatives of private enterprises. However, we note that the group shown, in some way, to be closed. The "new" people participation into the group is accepted, as long as, is communicated in advance. "Although more people actually generate more discussion, meetings may take longer .... They think that the "new" person brings an issue that has already been decided or that it is of his/her interest only" (Member 6).

\section{FINAL REMARKS}

This study analyzed the trajectory and dynamics of the Grupo Gestor do Turismo Rural do Rio Grande do Sul (a rural tourism steering group) and its characterization as an interorganizational collaborative network. The application of collaborative networks and social capital theories were essential to understand the group dynamics and to study actors who constitute it, what Garcia (2006) calls "intentional agents". These intentional agents have economic and social motivations, whose actions are influenced by network relationships in which they are embedded.

As a result, it can be stated that the Grupo Gestor do Turismo Rural do Rio Grande do Sul can be considered a collaborative network, due to the variety of entities, both public and private organizations, which work directly or indirectly with the rural tourism segment. These organizations operate largely 
autonomously and heterogeneously, geographically distributed and are working together to better achieve common or compatible goals, through interactions mediated by communication tools, especially through the Internet.

The results of the empirical study confirmed that the network switches operationally moments between collaboration and independent work, corroborating the statement of Camarinha-Matos \& Afsarmanesh (2008), that collaboration in collaborative networks, in its strict sense, does not happens all the time.

The Group can be considered as a strategic network, because its composition differs by the combination of complex reciprocal relations, which is more cooperative than competitive (Loyola \& Moura, 1996). Besides that, it promotes discussion and common actions in benefit of many. It has relative stability, and depends on the coordination of an agent (in this case, the SETUR). The expectation is that from the formulation of a State Policy, funds can be directed to the actions chosen by the group. The elements of social capital identified according to the Nahapiet \& Ghoshal (1998) model, show that most significant were the relational and structure dimensions.

The analysis dimensions of social capital showed an overlap, making it difficult to analyze data accurately. Taking, for example, the elements of the relational dimension (trust, norms of reciprocity, obligations and expectations, and identification), which are major influencers to support a collaborative network, we noticed that these elements occur also because there are codes, languages and shared narratives, which in a way, are also present in the cognitive dimension.

At the same time, these two dimensions occur because the network structure enables them to occur. However, it is indeed a valid application of these dimensions for understanding the network as a whole, because they are really important elements for strengthening relations between participants of the network and for the actions resulting from their joint work.

Although the group is going through a time of uncertainty and change, it is possible to notice the presence of reasonable stock of social capital. If there was a lack of that stock the results achieved by the group could not be satisfactory and would not have a predisposition to achieve the level of cooperation showed.

It is advisable that members, in spite of people-link (those with a larger stock of social capital), continue to foster relationships based on trust and commitment to ensure the benefits in information exchange and access. The norms of reciprocity will be fundamental to the next step - the redefinition of a formal, legal structure towards the State. These elements of social capital, identified as major influencers for network support will be decisive for the continuity of the group. We believe that this continuity will depend on understanding that it can be strengthened, even while the new governance system is still built. Even with some degree of divergence, there are evidences that the group will be strengthened, since it does not jeopardize the basic fundamentals of group cohesion, as indicated by Camarinha-Matos \& Afsarmanesh (2008): trust, sharing and justice.

\section{ACKNOWLEDGES}

This work is being supported by the University of Caxias do Sul (Universidade de Caxias do Sul - UCS), the National Counsel for Scientific and Technological Development (Conselho Nacional de Desenvolvimento Científico e Tecnológico - $(N P q)$ and the Coordination for the Improvement of Higher Education Personnel (Coordenação de Aperfeiçoamento do Pessoal de Nível Superior-Capes). 


\section{REFERENCES}

Albagli, S., \& Maciel, M. L. (2003). Capital social e desenvolvimento local. In: Lastres, H. M. M.; Casssiolato, J.E., \& Maciel, M.L. (Orgs.). Pequena empresa: cooperação e desenvolvimento local . Rio de Janeiro: Relume Dumará, pp. 423-440.

Andion, C., \& Serva, M. (2006). A etnografia e os estudos organizacionais. In: Silva, A. B., \& Godoi, C. K., \& Bandeira-de-Mello, R. Pesquisa qualitativa em estudos organizacionais: paradigmas, estratégias e métodos. São Paulo: Saraiva, pp. 147-179.

Bardin, L. (2000). Análise de conteúdo. Lisboa: Edições 70.

Barquero, A. V. (2002). Desenvolvimento endógeno em tempos de globalização. Porto Alegre: Editora da UFRGS.

Beni, M. C. (2006). Política e planejamento de turismo no Brasil. São Paulo: Aleph.

Bourdieu, P. (2006). O poder simbólico. 9. ed. Rio de Janeiro, RJ: Bertrand Brasil.

Brasil (2004). Ministério do Turismo. Secretaria Nacional de Políticas de Turismo: Coordenação Geral de Segmentação (Programa de Regionalização do Turismo. Roteiros do Brasil: diretrizes para o desenvolvimento do turismo rural. Brasília: Ministério do Turismo.

Brasil (2006). Ministério do Turismo. Secretaria Nacional de Políticas de Turismo: Coordenação Geral de Segmentação (Marcos Conceituais). Brasília: Ministério do Turismo.

Burt, R. S. (1992). Structural holes: the social structure of competition. Cambridge: Harvard University Press.

Camarinha-Matos, L. M., \& Afsarmanesh, H. (2007). A framework for virtual organization creation in a breeding environment. Annual Reviews in Control, 31 (1), pp. 119-135.

Camarinha-Matos, L. M., \& Afsarmanesh, H. (2008). Collaborative networks: reference modeling. New York: Springer.

Camarinha-Matos, L. M., et al. (2009). Collaborative networked organizations: concepts and practice in manufacturing enterprises. Computers \& Industrial Engineering, 57 (1), pp. 46-60.

Camarinha-Matos, L. M., \& Macedo, P. (2010). A conceptual model of value systems in collaborative networks. Journal of Intelligent Manufacturing, 21 (3), pp. 287-299.

Campanhola, C., \& Graziano da Silva, J. (1999). Panorama do turismo rural brasileiro. In: Oliveira, C. G. S., Moura, J. C., Sgai, M. (Eds.). Turismo no espaço rural brasileiro. Piracicaba: Fealq, pp. 9-42.

Campanhola, C. (2000). O agroturismo como fonte de renda para o pequeno agricultor brasileiro. In: Almeida, J. A., \& Riedl, M. Turismo rural: ecologia, lazer e desenvolvimento. Bauru: Edusc, pp. 145-179.

Coleman, J. S. (1988). Social capital in the creation of human capital. American Journal of Sociology, 94, S95S120. 
Coleman, J. S. (1990). Foundations of social theory. Cambridge: Harvard University Press.

Coleman, J. S. (2000). Social capital in the creation of human capital. In: Lesser, E. L. Knowledge and Social Capital. Boston: Butterworth-Heinemann.

D`Araújo, M. C. (2003). Capital Social. Rio de Janeiro: Jorge Zahar Editor.

Dinda, S. (2008). Social Capital in the Creation of Human Capital and Economic Growth: a productive consumption approach. The Journal of Socio-Economics, 37 (1), 2020-2033.

Evans, P. (1996). Government action, social capital and development: Reviewing the evidence on synergy. World Development, 24, (6), 1119-1132.

Fukuyama, F. (1996). Confiança. Rio de Janeiro: Rocco.

García, M. S. (2006). Social capital, networks and economic development: an analysis of regional productive systems. Cheltenham: E. Elgar.

Gaskell, G. (2003). Entrevistas Individuais e Grupais. In: Bauer, M. W., \& Gaskell, G. Pesquisa qualitativa com texto, imagem e som: um manual prático. 2. ed. Petrópolis: Vozes.

Godoy, A. (2006). Estudo de caso qualitativo. In: Silva, A. B., Godoi, C. K., \& Bandeira-de-Mello, R. Pesquisa Qualitativa em Estudos Organizacionais: paradigmas, estratégias e métodos. São Paulo: Saraiva.

Goldenberg, M. (1999). A arte de pesquisar: como fazer pesquisa qualitativa em ciências sociais. 3. ed. Rio de Janeiro: Record.

Granovetter, M. S. (1985). Economic Action and Social Structure: The Problem of Embeddedness. American Journal of Sociology, 91 (3), pp. 481-510.

Granovetter, M. S. (1992). Problems of explanation in economic sociology. In: Nohria, N., \& Eccles, R. G. Networks and organizations: structure, form and action. Boston: Harvard Business School Press. pp.25-56.

Graziano da Silva, J., \& Vilarinho, C., \& Dale, P. J. (2004). Turismo em áreas rurais: suas possibilidades e limitações no Brasil. In: Almeida, J. A., \& Froehlich, J. M., \& Riedl, M. Turismo rural e desenvolvimento sustentável Campinas: Papirus. pp. 15-62.

Hair Jr, J. F. (2005). Fundamentos de métodos de pesquisa em administração. Porto Alegre: Bookman.

Inkpen, A. C., \& Tsang, E. W. K. (2005). Social capital networks, and knowledge transfer. Academy of Management Review, 30 (1), pp. 146-165.

Kastenholz, E., \& Lima, J. (2013). Co-creating quality rural tourism experiences - the case of a Schist Village in Portugal. International Journal of Management Cases, 15(4), pp. 193-204.

Lesser, E. L. (2000). Leveraging Social Capital in Organizations. In: Lesser, E. L. Knowledge and Social Capital. Boston: Butterworth-Heinemann. 
Loyola, E., \& Moura, S. (1996). Análise de Redes: uma Contribuição aos estudos organizacionais. In: Fischer, T.Gestão contemporânea, cidades estratégicas e organizações locais. Rio de Janeiro: FGV. pp. 53-68.

Macke, J., Vallejos, R. V., Faccin, K., Genari, D. (2012). Social Capital in Collaborative Networks Competitiveness: the case of the Brazilian Wine Industry Cluster. International Journal of Computer Integrated Manufacturing, 25 (1), pp. 1-8.

Mishira, A. K. (1996). Organizational responses to crisis: the centrality of trust. In: Kramer, R. M., \& Tyler, T. Trust in Organizations: frontiers of theory and research. Newbury Park: Sage. pp. 261-287.

Muls, L. M. (2008). Desenvolvimento Local, Espaço e Território: O Conceito de Capital Social e a Importância da Formação de Redes entre Organismos e Instituições Locais. Revista Economia, 9 (1), pp. 1-21.

Nahapiet, J., \& Ghoshal, S. (1998). Social Capital, Intellectual Capital, and the Organizational Advantage. Academy of Management Review, 23 (2), pp. 242-266.

Oliveira, C. G. S, \& Moura, J. C., \& Sgai, M. (2001). Turismo no espaço rural brasileiro. Piracicaba: Fealq.

Portes, A. (2000a). Social Capital: Its Origins and Applications in Modern Sociology. In: Lesser, E. L. Knowledge and Social Capital. Boston: Butterworth-Heinemann.

Portes, A. (2000b). Capital social: origens e aplicações na sociologia contemporânea. Sociologia. Problemas e Práticas, 33 (1), pp. 133-158.

Portuguez, A. P. (1999). Agroturismo e desenvolvimento regional. São Paulo: Contexto.

Putnam, R. D. (1993). The Prosperous Community: Social Capital and Public Life. American Prospect, 13 (1), pp. 35-42.

Putnam, R. D. (1995). Bowling Alone: America's declining social capital. Journal of Democracy, 6 (1), pp. 6578.

Rio Grande do Sul (2010). Secretaria de Turismo Esporte e Lazer do Estado do Rio Grande do Sul - SETUR. Regimento Interno do Grupo Gestor do Turismo Rural. Porto Alegre: SETUR.

Roque, A. M. (2001). Turismo no Espaço Rural: um estudo multicaso nas regiões sul e sudoeste de Minas Gerais. 106p. Dissertação (Mestrado em Administração Rural). Universidade Federal de Lavras, Lavras, Minas Gerais.

Rosas, J., \& Camarinha-Matos, L. M. (2009). An approach to assess collaboration readiness. International Journal of Production Research, 47 (17), pp. 4711-4735.

Schwartzman, H. B. (1993). Ethnography in Organizations. Newbury Park: Sage Publications.

Sharpley, R. (2002). Rural tourism and the challenge of tourism diversification: the case of Cyprus.Tourism Management, 23(3), pp. 233-244.

Silva, M. G. L. (2004). Cidades turísticas: identidades e cenários de lazer. São Paulo: Aleph. 
Tulik, O. (2003). Turismo Rural. São Paulo: Aleph.

Veiga, J. E. (2002). Cidades imaginárias: o Brasil é menos urbano do que se calcula. Campinas: Autores Associados.

Yin, R. K. (2005). Estudo de caso: planejamento e métodos. (3ạ ed.). Porto Alegre: Bookman.

Zimmermann, A. (1996). Turismo Rural: um modelo brasileiro. Ed. do autor: Florianópolis.

Artigo recebido em: 10/12/2012. Artigo aprovado em: 17/02/2014. 